REVISTA

MEXICANA DE

ECONOMÍA Y

FINANZAS

REMEF

(TIIE MEXICAN JOURNAL OF

ECONOMICS AND FINANCE)
Revista Mexicana de Economía y Finanzas, Nueva Época

Volumen 17 Número 1, Enero - Marzo 2022, pp. 1-15, e703

DOI: https://doi.org/10.21919/remef.v17i1.703

(Received: September 17, 2020, Accepted: March 10, 2021.

Published: September 10, 2021)

\title{
A New Index for Public Investment Management
}

\author{
Antonio Rojas Canela ${ }^{1}$ - Universidad Nacional Autónoma de México, México \\ Juan Carlos Moreno-Brid2 - Universidad Nacional Autónoma de México, México
}

The objective of this article is to improve the most widely used indicator of quality in public investment management (the PIMI). The methodology was to use an alternative algorithm to build a new version of the PIMI and calculate it for sixteen Latin American countries. The result is a New PIMI that appears better than the original one, as it has a positive correlation with an objective indicator of the efficiency of public investment, which is not achieved by the original PIMI. We recommend the use of the New PIMI, proposed here, as a control variable in studies on aggregated public investment and its impacts on economic growth and social welfare. One limitation of the New PIMI is that it reflects the quality of public investment management at the aggregate level and based on de jure criteria, thus not capturing key differences that occur at a more disaggregated or informal level. Even so, the relevance, originality and replicability of the New PIMI make it a significant contribution to knowledge in this field.

JEL Classification: H54, H6, C43.

Keywords: public investment management, national system of public investment, public investment efficiency, PIMI, New PIMI.

\section{Un nuevo índice para la gestión de la inversión pública}

El objetivo de este artículo es mejorar el indicador más utilizado sobre la calidad en la gestión de la inversión pública (Public Investment Management Index, PIMI). La metodología fue utilizar un algoritmo alternativo para construir una nueva versión del PIMI y calcularlo para dieciséis países latinoamericanos. El resultado es un Nuevo PIMI que parece mejor que el anterior, ya que tiene una correlación positiva con un indicador objetivo de la eficiencia de la inversión pública, lo que no logra el PIMI original. Recomendamos el uso del Nuevo PIMI, aquí propuesto, como variable de control en los estudios sobre la inversión pública agregada y sus impactos en el crecimiento económico y bienestar social.

Una limitación del Nuevo PIMI es que refleja la calidad de la gestión de la inversión pública a nivel agregado y con base en criterios de jure, pero no permite capturar las diferencias en la eficiencia de dicha gestión que pueden ocurrir a nivel más desagregado o informal. Aun así, la originalidad y replicabilidad del Nuevo PIMI constituyen un aporte significativo al conocimiento del tema.

Clasificación JEL: H54, H6, C43.

Palabras clave: gestión de la inversión pública, sistemas nacionales de inversión pública, eficiencia de la inversión pública, PIMI, nuevo PIMI.

1 Corresponding author. Facultad de Economía, UNAM. Email: antonio.rocanela@gmail.com

2 Email: mbrid@economia.unam.mx

* No source of funding for research development 


\section{Introduction}

The benefits of governmental investments could be very low or even null if they are geared to projects that are not suitable (Pritchett, 2000). Some studies (McKinsey Global Institute, 2013) have shown that there can be considerable economic and social gains if the selection of such investment projects is improved and existing assets are used to the best of their ability. Others have provided evidence that correlation between public investment and economic growth depends to a certain extent on the, say, quality of such investment (Gupta et. al., 2014). Thus, making better public investment decisions can help to free up resources for other important needs, to have a more favorable impact on infrastructure with the same amount of resources, and thus to enhance growth. This issue is very relevant in developing countries, like those of Latin America, characterized by having significant infrastructure gaps, of the order of various points of GDP (Sánchez et. al. 2017).

Some recent studies have focused on the task of how to close the infrastructure gaps relying less on increasing the aggregate level of investment and more on a more efficient allocation of resources (Serebrisky et. al., 2017; Suárez-Alemán, Serebrisky \& Perelman, 2019). Some of these authors (Serebriky et. al., op. cit.) estimated savings equivalent to $1 \%$ of Latin America's GDP if countries improve the efficiency of public investments. Clearly, a powerful tool to close infrastructure gaps -and thus stimulate long-term economic growth- can be a better management of investment projects.

Large infrastructure projects require a lot of planning in the pre-investment phase, including studies on technical, socioeconomic, and environmental issues. Besides, these projects normally face political challenges that range from public debate on their relevance to parliamentary work to grant them financing. Clearly an institutional and organizational framework is indispensable to better ensure that different stages in the life cycle of projects are carried out optimally.

Since every country has its own legal framework, there are notable differences in the public investment processes among countries. This creates an opportunity for making comparative studies and finding the best practices to recommend improvements for the quality of public investment management. However, there is not much literature on this topic, and there is just one index aimed at measuring that quality: The Public Investment Management Index (PIMI) by Dabla-Norris et. al. (2012). This index filled an unattended gap in the literature and works well for cross-country comparisons, but it is not replicable since most of the information used on its construction is not open to public access.

This paper solves this problem by constructing a New PIMI, based on public information, theoretically robust and with a better performance in capturing key traits of management of public investment than the original one. The main contribution of this article is this New PIMI, which can be used to better compare the quality of public investment management between countries. This is relevant because existing studies on public investment generally try to measure its impact on other variables like economic growth or private investment (see Sturm et. al, 1998; Romp \& De Haan, 2007; Das, Das \& Ray, 2018; Afonso \& Aubin, 2019), but they never take its quality into account. With the New PIMI, it is possible to include such trait as a control variable in future studies on public investments and their macroeconomic impacts. 
The remainder of this article proceeds as follows. Section 2 provides a brief literature review, while section 3 describes the original PIMI and the construction of a new one. Section 3 also elaborates on the robustness of this New PIMI under different weighting schemes. Section 4 presents the relation between PIMI and other indices related to some institutional characteristics. In this fourth section, the New PIMI is correlated against the ratio between increases in public capital and the amount of public investment, as a proxy of its efficiency. Finally, section 5 draws conclusions and topics for further research.

\section{Literature review}

In recent years there has been an increasing interest regarding the relationship between public investment and the quality of institutions, management, and governance. This is not surprising since institutions and state capacity play a critical role in determining whether public investments will generate productive assets, or be a waste of valuable resources. For instance, Grigoli and Mill (2014) studied the relation between institutional quality and the level of public investment and provided tentative evidence of a positive effect from the quality of governance to the quality of infrastructure. This last point was also stated by Albino-War et. al. (2014), and Baum, Mogues, and Vernier (2020), among others, and was the starting point for an International Monetary Fund's Staff Report (2015).

With the World Bank as the main supporter institution, another part of the literature has put the emphasis on finding the best practices for public investment management. In this regard, authors like Rajaram et. al. (2010) have contributed by constructing the first diagnostic framework for assessing this management, identifying eight "must-have" features of a well-functioning public investment system: i) investment guidance, project development, and preliminary screening; ii) formal project appraisal; iii) independent review of appraisal; iv) project selection and budgeting; v) project implementation; vi) project adjustment; vii) facility operation; and viii) project evaluation. Subsequently, Rajaram et. al. (2014) built on this framework to apply it to country experiences and explain in detail some of the features aforementioned.

But the theoretical foundations of evaluation of public investment projects (and therefore of its management) can be traced back to Harberger's (1971) three postulates ${ }^{3}$, which are the underlying assumptions of cost-benefit analysis (CBA), a mandatory requirement for the execution of investment projects in most of the countries.

Since Haberger's contributions were made in the early seventies, it was back then when countries started to establish the evaluation of public investment projects as a legal requirement to assign them resources. In Latin America, this led to the creation of National Systems of Public Investment (NSPI), with Chile as the pioneer.

Since then, NSPI have been studied extensively from a de jure perspective. Some authors evaluated the hits and misses of the NSPI in a particular country (Ahmad y Viscarra, 2016; Fontaine, 1997; Gómez-Lobo, 2012), while others have made comparisons between different NSPI (Rojas, 2019; Perroti \& Vera, 2015; Contreras, Cartes y Pacheco, 2010; Ortegón y Pacheco, 2005; Vizzio,

3 These postulates are 1) the competitive demand price for a given unit measures the value of that unit to the demander; 2) the competitive supply price for a given unit measures the value of that unit to the supplier; and 3) when evaluating the net benefits or costs of a given action, the costs and benefits accruing to each member of the relevant group should normally be added without regard to the individual(s) to whom they accrue. 
2000). Also, there are different classifications on NSPI and different approaches from which they are studied. Ortegón and Pacheco (op.cit.), for instance, distinguished between federal countries, in which there are intermediate levels of government with their own legal personality and the right to draft their own laws; and unitary, strongly centralized countries. The following analysis is closer to this last perspective.

\section{The Public Investment Management Index (PIMI) and its new version}

As Pritchett (2000) convincingly argued, when public investment is ineffective, cumulated and depreciated investment effort is not equal to capital. "A public sector steel mill may absorb billions as an 'investment', but if it cannot produce steel it has zero value as capital” (op. cit., p. 1). This means that only a fraction $(\gamma)$ of total public investment $\left(P I_{t}\right)$ is effectively converted into public capital stock in the next period $\left(P K S_{t+1}\right)$.

$$
P K S_{t+1}=\gamma P I_{t}+(1-\delta) P K S_{t}
$$

Where $\delta$ is the depreciation rate, and $\gamma$ could then be said to be a parameter of public investment efficiency. Dabla-Norris et. al. (op. cit.) tried to approximate to this parameter through the institutional environment underpinning its management by focusing on four stages of the public investment process: strategic guidance and project appraisal; project selection; project management and implementation; and project evaluation and audit. These four stages were made up of several individual components (17 in total), each of which was presented as a question and then evaluated with a score that ranges from zero to four, where higher values correspond to a better performance of the country in that specific component.

The data used in the construction of the PIMI were compiled from many different sources, with the World Bank Public Investment Management (PIMs) case studies and the World Bank Public Expenditure Reviews (PERs) as the primary source of information. However, these sources have a serious problem. As the authors stated explicitly, PIMs and PERs "relied on in-country discussion with country officials, review of published and unpublished material, and discussions with relevant stakeholders" (op. cit. 244). Thus, much of the information used for those studies and, therefore, in the construction of the index is not open to public access. Furthermore, Dabla-Norris et. al. warned that PIMs and PERs were not sufficient to score the 17 questions for every country, so they "sent a short questionnaire to World Bank public finance experts and country economists" to supplement the information. Therefore, it is impossible to replicate the PIMI unless the researcher could contact local officials and a lot of experts from organizations such as the World Bank.

Despite the above, the PIMI works well for cross-country comparisons and is fairly robust in the sense that notable changes in the weighting and aggregation do not reflect in substantial changes in the country scores and ranking. The PIMI also has the expected correlation with other variables, such as per capita GDP, and control of corruption, but it does not have the expected correlation when plotted against an objective indicator of public investment efficiency, as it will be seen in section 4 of 
this work. This implies that original PIMI could be substantially enhanced, which is why we build a new one in the following section.

\subsection{Construction of a New PIMI: the cases of Latin America}

As it was stated in the introduction to this paper, an institutional-organizational framework is needed to ensure that the processes through which public investments go through are carried out optimally. Unlike other regions in the world, many Latin American countries have formally recognized these frameworks in their laws, as National Systems of Public Investment (NSPI). Moreover, supported by the Inter-American Development Bank and the Economic Commission of Latin America and the Caribbean, they have created a "Red SNIP (NSPI Network)" in which they share their experiences. This makes Latin American countries especially comparable between them.

Since Dabla-Norris et. al. (op. cit.) did not calculate the PIMI for most of the Latin American countries, Armendáriz et. al. (2016) replicated it for these countries, using the very same 17 characteristics as the former authors, but instead of presenting them as being continuous variables, they presented them as being dichotomous.

The New PIMI presented in this paper was constructed following this idea, by taking desirable characteristics on the NSPI and adding a point to each country for each of those characteristics that are present in its case. Each characteristic could be said to be a dichotomous variable, which takes a value of one if it is present and zero otherwise. Twelve characteristics were considered that deal with the process and evaluations that investment projects go through, the faculties and duties that the NSPI authorities have, and the transparency of information on public investments. Another nonbinary variable was considered, which stands for the antiquity of the NSPI as part of the legal framework (question three in table 1). Since Chile and Costa Rica created their NSPI in 1975, they now have been operable for 45 years, so this third variable takes a value of one in the cases of these two countries, zero in the cases where NSPI does not formally exist yet, and fluctuates in the interval $(0,1)$ in the other countries, according to the age of the NSPI in each one. Then, these thirteen characteristics were grouped into four categories (legal support and experience, processes and methodologies for the pre-investment phase, planning and budgeting, and accountability and transparency) each of which was evaluated on a 100 scale based on the values obtained for the dichotomous variables that make them up.

The first one considers the existence of a legally/formally recognized NSPI and its authority, for this is important to give legal support to the system. The second category captures the technical capacities of the system to evaluate investment projects at a micro level, while the third one captures its capacity to select and prioritize projects and to plan the investments in the medium and long terms (a political and macro-level). Finally, the fourth category captures the transparency of the system and its institutional capacities to evaluate projects while they are being executed and once they are operating. Table 1 presents these characteristics and categories, which are in line with what Rajaram et. al. (2010) and the World Bank (Kim, Fallov \& Groom, 2020) understand as "Must Have" features for an efficient public investment system. Moreover, characteristics presented in table 1 address, to a lesser extent, the same four stages of the public investment process considered by Dabla-Norris et. al. (op. cit). 
Table 1. Desirable characteristics for public investment systems

\begin{tabular}{|l|l|}
\hline \multirow{4}{*}{$\begin{array}{l}\text { Legal support and } \\
\text { experience }\end{array}$} & $\begin{array}{l}\text { (1) Is the existence of the NSPI legally recognized? } \\
\text { central government? }\end{array}$ \\
\cline { 2 - 3 } $\begin{array}{l}\text { Quality of pre-investment How long has the NSPI been formally recognized? (45 years = 1, } \\
\text { phase (technical/micro) }\end{array}$ & $\begin{array}{l}\text { (3) if not yet recognized) } \\
\text { projects? }\end{array}$ \\
\cline { 2 - 3 } of the projects?
\end{tabular}

Source: Authors' elaboration

To answer the questions presented above, an extensive review of the legal framework was carried out at the national level for each one of sixteen Latin American countries. Most countries in this cohort have a specific law to control and regulate public investments, and a single website that gathers all the information regarding it, from planning to project banks and official reports. Nonetheless, there are some countries (Brazil, Colombia, El Salvador, Nicaragua, and Mexico) in which this information is dispersed within several documents and websites, but the information obtained from official sources was enough to complete table 2, where it is shown if these sixteen countries meet the desirable characteristics exposed in table 1, and the obtained score for each country in each one of the four categories. The last column shows the value of the New PIMI for each country as the unweighted average of the four categories. 
Table 2. Answering the questions: the New PIMI

\begin{tabular}{|c|c|c|c|c|c|c|c|c|c|c|c|c|c|c|c|c|c|c|}
\hline 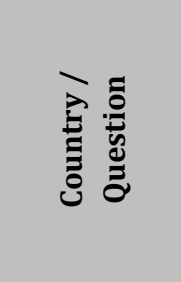 & $\mathbf{1}$ & 2 & 3 & 4 & 5 & 6 & 7 & 8 & 9 & 10 & 11 & 12 & 13 & 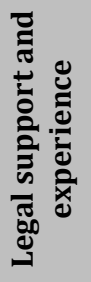 & 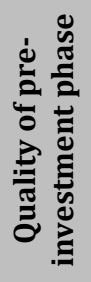 & 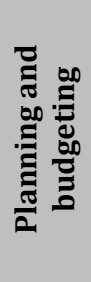 & 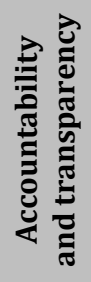 & $\begin{array}{l}\text { New } \\
\text { PIMI }\end{array}$ \\
\hline Chile & 1 & 1 & 1.0 & 1 & 1 & 1 & 1 & 0 & 1 & 1 & 1 & 1 & 0 & 100 & 100 & 67 & 100 & 92 \\
\hline Paraguay & 1 & 1 & 0.2 & 1 & 1 & 1 & 1 & 1 & 1 & 0 & 1 & 1 & 0 & 73 & 100 & 100 & 67 & 85 \\
\hline Costa R. & 1 & 1 & 1.0 & 1 & 1 & 1 & 1 & 1 & 1 & 0 & 0 & 1 & 0 & 100 & 100 & 100 & 33 & 83 \\
\hline Bolivia & 1 & 1 & 0.5 & 1 & 1 & 1 & 1 & 1 & 0 & 0 & 0 & 1 & 1 & 84 & 100 & 67 & 67 & 79 \\
\hline Peru & 1 & 1 & 0.4 & 1 & 1 & 1 & 1 & 1 & 1 & 0 & 0 & 1 & 0 & 81 & 100 & 100 & 33 & 79 \\
\hline Panama & 1 & 1 & 0.4 & 1 & 1 & 0 & 1 & 1 & 1 & 0 & 1 & 1 & 0 & 81 & 67 & 100 & 67 & 79 \\
\hline Dom. Rep. & 1 & 1 & 0.3 & 1 & 0 & 0 & 1 & 1 & 1 & 0 & 1 & 1 & 1 & 77 & 33 & 100 & 100 & 78 \\
\hline Colombia & 1 & 1 & 0.2 & 1 & 0 & 1 & 1 & 1 & 0 & 1 & 0 & 1 & 1 & 74 & 67 & 67 & 100 & 77 \\
\hline Mexico & 0 & 1 & 0.0 & 1 & 1 & 1 & 1 & 0 & 0 & 0 & 1 & 1 & 1 & 34 & 100 & 33 & 100 & 67 \\
\hline Argentina & 1 & 1 & 0.6 & 1 & 1 & 0 & 1 & 1 & 0 & 0 & 0 & 1 & 0 & 86 & 67 & 67 & 33 & 63 \\
\hline Nicaragua & 1 & 1 & 0.4 & 1 & 1 & 1 & 0 & 1 & 0 & 0 & 0 & 1 & 0 & 81 & 100 & 33 & 33 & 62 \\
\hline Ecuador & 1 & 1 & 0.3 & 1 & 1 & 0 & 0 & 1 & 0 & 1 & 0 & 1 & 0 & 77 & 67 & 33 & 67 & 61 \\
\hline Uruguay & 1 & 1 & 0.2 & 1 & 1 & 1 & 0 & 0 & 0 & 0 & 1 & 1 & 0 & 73 & 100 & 0 & 67 & 60 \\
\hline Guatemala & 1 & 1 & 0.2 & 1 & 0 & 0 & 1 & 1 & 1 & 0 & 0 & 1 & 0 & 72 & 33 & 100 & 33 & 60 \\
\hline El Salvador & 1 & 1 & 0.7 & 1 & 1 & 0 & 0 & 1 & 0 & 0 & 0 & 1 & 0 & 89 & 67 & 33 & 33 & 56 \\
\hline Brazil & 0 & 0 & 0.0 & 1 & 0 & 0 & 0 & 1 & 0 & 0 & 1 & 1 & 0 & 0 & 33 & 33 & 67 & 33 \\
\hline
\end{tabular}

Source: Authors' calculations based on laws and official documents (see reference list)

According to the New PIMI, Chile is the country with the highest quality on its public investment management, followed by Paraguay, Costa Rica, Bolivia, Peru, and Panama; while the worst evaluated countries are El Salvador and Brazil. This notably contrasts with the original PIMI, where Brazil was the highest-ranked of four Latin American countries, followed by Colombia, Peru, and Bolivia.

\subsection{Alternative aggregating schemes}

The New PIMI presented above is constructed as the unweighted average of four sub-indexes. However, it could be said that some characteristics are more important than others and that scores and rankings could substantially change if different weights are assigned for every category or subindex. In what follows, we test how big these changes are by assigning, both discretionally and randomly, different weights to each one of the sub-indexes.

\subsubsection{The discretional weighting}

Four different weighting schemes were constructed, assigning a higher weight to each one of the four categories. In the first one ("legal" scheme in table 3), legal support and experience account for twice 
the weight of the other categories, while in the second one ("technical" scheme in table 3), the double weight is assigned to quality of the pre-investment phase. In the third one ("political" scheme in table 3 ), the double weight is assigned to planning and budgeting and the last scheme ("accountable" in table 3) considered a double weight for accountability and transparency.

The first column in Table 3 shows the score and ranking of the New PIMI with the original non-weighted scenario, while the other columns do the same under the four discretional-alternative weighting schemes. As can be seen, and with exception of Costa Rica in scenario D, the top three highest values for New PIMI are always composed of the same countries (Chile, Paraguay, and Costa Rica); while Brazil is always the worst-ranked country, followed by El Salvador, which has some of the lowest values for every alternative weighting. Thus, it could be said that the New PIMI is robust to alternative-discretional weighting schemes. Only Uruguay, Mexico, and Costa Rica have a score that notably changes from one weighting to another, which can be seen in the last column of Table 3 , where these three countries show a standard deviation higher than 6 in their scores.

Table 3. New PIMI: Country scores and ranking unweighted and with four discretional weighting schemes (rank in parenthesis)

\begin{tabular}{|l|c|c|c|c|c|c|}
\hline Country & Unweighted & Legal & Technical & Political & Accountable & Std. Dev. \\
\hline Chile & $92(1)$ & $93(1)$ & $93(1)$ & $87(2)$ & $93(1)$ & 2.6 \\
\hline Paraguay & $85(2)$ & $83(3)$ & $88(2)$ & $88(1)$ & $81(4)$ & 3.0 \\
\hline Costa Rica & $83(3)$ & $87(2)$ & $87(3)$ & $87(2)$ & $73(7)$ & 6.1 \\
\hline Bolivia & $79(4)$ & $80(4)$ & $84(4)$ & $77(7)$ & $77(5)$ & 2.9 \\
\hline Peru & $79(4)$ & $79(5)$ & $83(5)$ & $83(4)$ & $70(9)$ & 5.3 \\
\hline Panama & $79(4)$ & $79(5)$ & $76(6)$ & $83(4)$ & $76(6)$ & 2.9 \\
\hline Dom. Rep. & $78(7)$ & $77(7)$ & $69(10)$ & $82(6)$ & $82(2)$ & 5.3 \\
\hline Colombia & $77(8)$ & $76(8)$ & $75(7)$ & $75(8)$ & $81(3)$ & 2.5 \\
\hline Mexico & $67(9)$ & $60(15)$ & $73(8)$ & $60(11)$ & $73(7)$ & 6.5 \\
\hline Argentina & $63(10)$ & $68(9)$ & $64(12)$ & $64(10)$ & $57(12)$ & 3.9 \\
\hline Nicaragua & $62(11)$ & $66(10)$ & $69(9)$ & $56(12)$ & $56(13)$ & 5.8 \\
\hline Ecuador & $61(12)$ & $64(11)$ & $62(13)$ & $55(13)$ & $62(10)$ & 3.4 \\
\hline Uruguay & $60(13)$ & $62(12)$ & $68(11)$ & $48(15)$ & $61(11)$ & 7.3 \\
\hline Guatemala & $60(13)$ & $62(12)$ & $54(15)$ & $68(9)$ & $54(14)$ & 5.9 \\
\hline El Salvador & $56(15)$ & $62(12)$ & $58(14)$ & $51(14)$ & $51(15)$ & 4.7 \\
\hline Brazil & $33(16)$ & $27(16)$ & $33(16)$ & $33(16)$ & $40(16)$ & 4.6 \\
\hline
\end{tabular}

Note: See the first paragraph of this section for a definition of each of the weighting schemes Source: Authors' calculations.

\subsubsection{The random weighting}

500 different scenarios were constructed with a random weighting, using the next algorithm:

1. A $500 * 4$ order matrix " $w$ " was constructed, which contains 500 different random combinations of weights for each one of the four categories. By construction, the sum of the four weights adds to one.

2. The next step was to solve the following expression: 


$$
W=w * c
$$

Where $c$ is a $4 * 16$ order matrix that contains the shadowed values of table 2 . The result is a $500 * 16$ order matrix that contains the New PIMI with 500 alternative random weighting schemes. Table 4 presents the descriptive statistics of matrix $W$.

Table 4. New PIMI: Descriptive statistics for 500 alternative-random weighting schemes

\begin{tabular}{|c|c|c|c|c|c|c|}
\hline $\begin{array}{l}\text { Country / } \\
\text { Statistic }\end{array}$ & Max & Mean & Min & $\begin{array}{l}\text { Std. } \\
\text { Dev. }\end{array}$ & $\begin{array}{l}\text { Number of times } \\
\text { that the country } \\
\text { reached the three } \\
\text { highest values }\end{array}$ & $\begin{array}{l}\text { Number of times } \\
\text { that the country } \\
\text { reached the three } \\
\text { lowest values }\end{array}$ \\
\hline Argentina & 74 & 61 & 41 & 4.9 & 0 & 17 \\
\hline Bolivia & 94 & 77 & 67 & 4.3 & 75 & 0 \\
\hline Brazil & 58 & 33 & 13 & 6.8 & 0 & 492 \\
\hline Chile & 100 & 91 & 74 & 4.9 & 422 & 0 \\
\hline Colombia & 92 & 74 & 64 & 4.6 & 82 & 0 \\
\hline Costa Rica & 100 & 83 & 48 & 8.7 & 280 & 0 \\
\hline Dom. Rep. & 99 & 75 & 44 & 8.7 & 159 & 19 \\
\hline Ecuador & 67 & 58 & 40 & 4.8 & 0 & 35 \\
\hline El Salvador & 73 & 54 & 34 & 6.7 & 0 & 342 \\
\hline Guatemala & 89 & 57 & 35 & 8.8 & 0 & 237 \\
\hline Mexico & 98 & 70 & 41 & 9.1 & 22 & 91 \\
\hline Nicaragua & 89 & 59 & 35 & 8.8 & 0 & 63 \\
\hline Panama & 93 & 76 & 67 & 4.6 & 30 & 0 \\
\hline Paraguay & 98 & 82 & 63 & 6.3 & 342 & 0 \\
\hline Peru & 97 & 77 & 48 & 8.8 & 88 & 0 \\
\hline Uruguay & 90 & 56 & 14 & 11.7 & 0 & 204 \\
\hline
\end{tabular}

Judging by the number of times that a country reaches the top three highest values of New PIMI, it could be said that Chile remains the country with the best public investment management, followed by Paraguay, Costa Rica, and the Dominican Republic. Excluding the latter, these countries were at the top of the ranking under both the basic-unweighted scheme and the discretional ones, so, again, the New PIMI appears to be fairly robust. On the other hand, Brazil, El Salvador, Guatemala, and Uruguay remain the worst performers since they are ranked at the bottom in almost every weighting scheme. It is important to say that, judging by the mean value, the random weighting would generate the very same ranking as the unweighted PIMI. Nonetheless, this would not capture differences in the variability of scores obtained for each country. Figure 1 presents the distribution of these 500 different scores on a box plot and, as shown, some countries have outliers that are concentrated at the top of the distribution (such as Nicaragua), while outliers from other countries (like Chile) are concentrated at the bottom. In other words, the frequency distribution is different for each country, so the mean is not a good indicator to construct the ranking. 


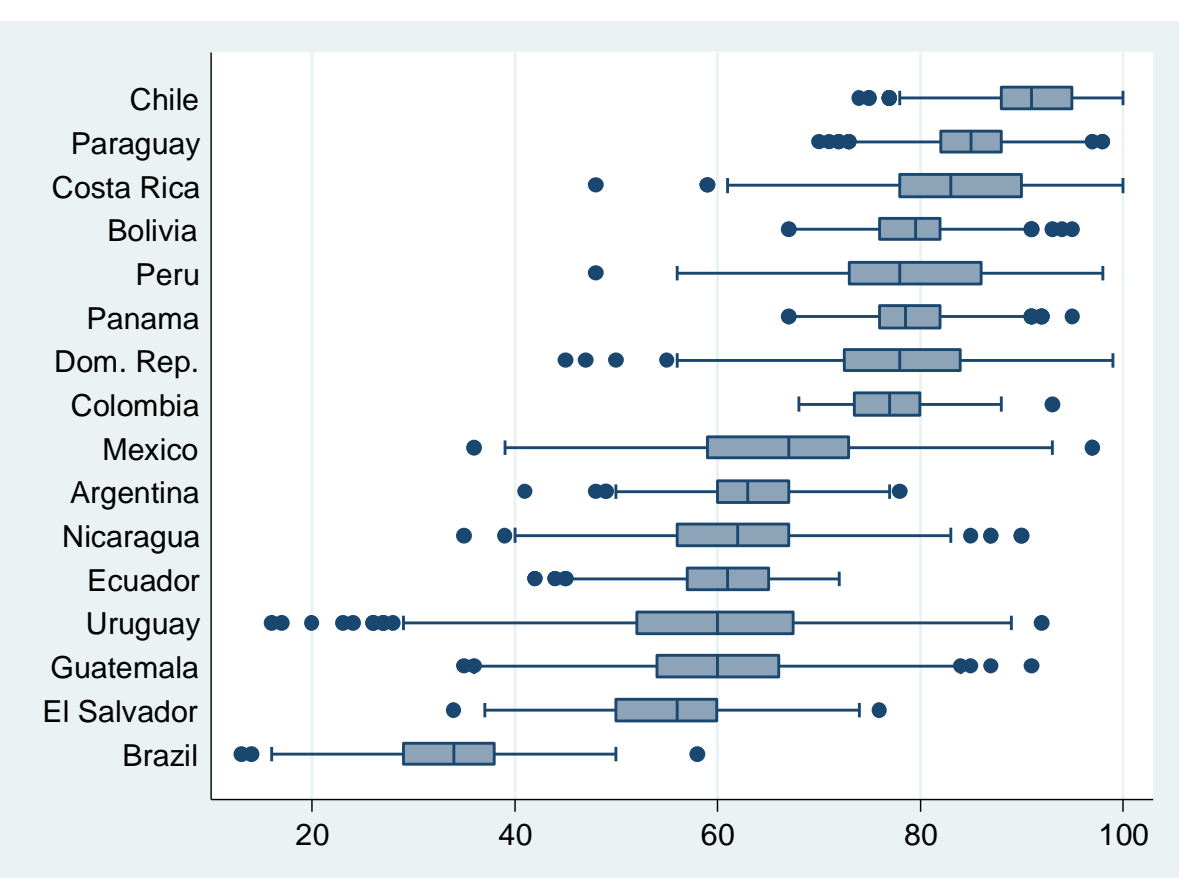

Figure 1. Box plot of the New PIMI for 500 different weightings

Source: Authors' calculations

\section{The relationship between the New PIMI with other selected indicators}

As was stated above, the objective of Dabla-Norris et. al. (op. cit.) was to approximate to parameter $\gamma$ in equation (1), which represents the amount of public investment that effectively becomes public capital. However, there is an easier way to calculate this parameter directly.

Solving for $\gamma$ in equation (1), we obtain it as the ratio of the increase in public capital stock, discounting depreciation, to the total amount of public investment:

$$
\gamma=\frac{P K S_{t+1}-P K S_{t}+\delta P K S_{t}}{P I_{t}}
$$

Then, $\gamma$ can be obtained if we know the depreciation rate, public investment amount, and the initial and final values of public capital stock. Nonetheless, there is no cross-country comparable data for the depreciation rate, at least to the Authors' knowledge, so we must accept the erroneous assumption that depreciation rates are invariant across countries ${ }^{4}$. Assuming a depreciation rate of $3 \% 5$, equation (2) becomes:

4 There are many reasons why depreciation rates could vary across countries, like financial constrains that induce the investors to choose less durable capital goods (Schündeln, 2013)

5 We choose this rate because it is the one used by some governments in Latin America (like Mexico and Peru) to calculate depreciation for infrastructure and buildings, while other countries (e.g. Ecuador) use a little higher depreciation rate (4\%). 


$$
\gamma=\frac{\left(P K S_{t+1}-0.97 P K S_{t}\right)}{P I_{t}}
$$

The higher the value of this ratio, the more efficient is the public investment, in the sense that a larger portion of it incorporates into the economy as new capital stock. To compare the value of $\gamma$ between countries, it was used the next index:

$$
P I E_{i}=\sum_{t=1989}^{t=2014} \frac{1}{26}\left\lceil\frac{\left(P K S_{i, t+1}-0.97 P K S_{i, t}\right)}{P I_{i, t}}\right\rceil
$$

Where PIE $i$, which stands for Public Investment Efficiency in country $i$, is the average of equation (3) in the period 1990-2015, and is expected to be highly and positively correlated with PIMI. Surprisingly, neither the original nor the New PIMI have this expected correlation, and, moreover, the correlation between the original PIMI and PIE is negative, which is exactly the opposite of the expected.
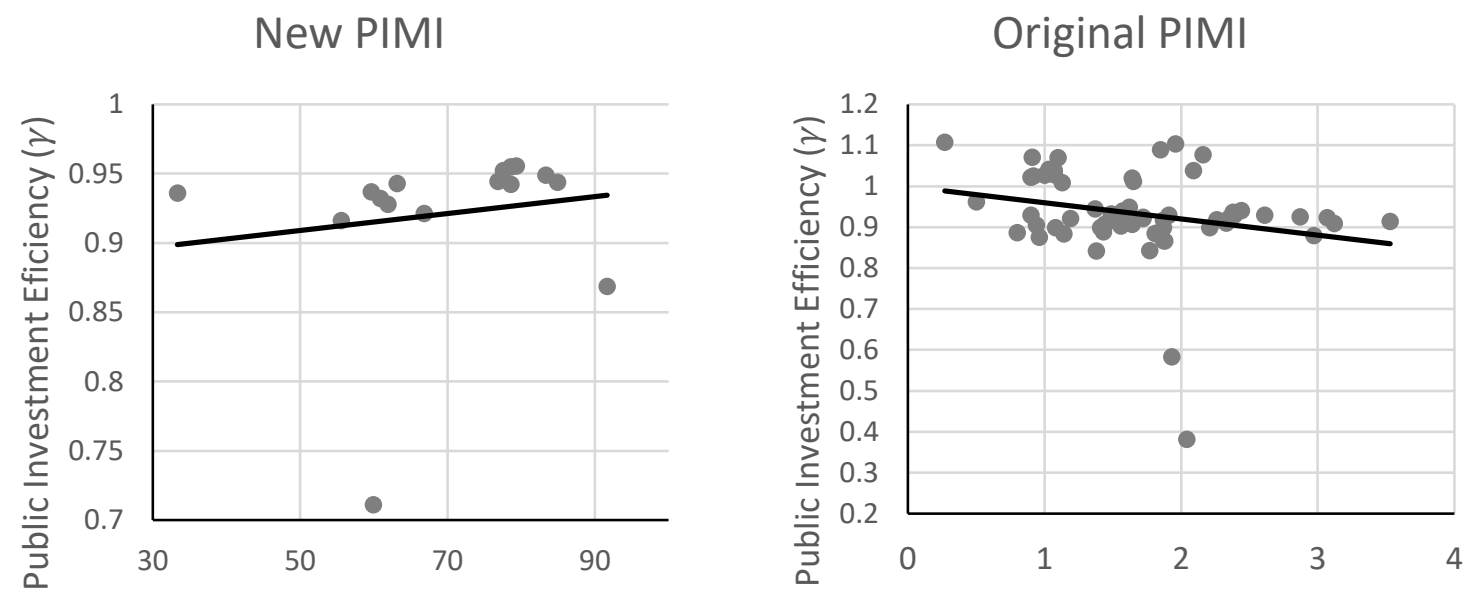

Figure 2. Public Investment Efficiency against new and original PIMI Source: Authors' calculations

Despite the above, both the original and New PIMI have reasonable correlations against other institutional variables, such as the rule of law, government effectiveness, control of corruption, and regulatory quality. As is shown in table 5, the New PIMI fits better than the original when correlated against variables as political stability and rule of law, but fits a little worse when correlated against government effectiveness, regulatory quality, and control of corruption. However, the main difference between new and original PIMI is that the latter shows a negative correlation against the PIE (which is exactly contrary to the expected), while the former shows a positive though low correlation. Since the PIE is a direct, aggregated, and objective way to measure public investment efficiency, it could be said that the best PIMI is the one that shows the highest correlation with PIE. It should be said that this difference is bigger when there are no assumptions on depreciation rates across countries.

Governments use this rate following the International Public Sector Accounting Standards by the International Federation of Accountants. 


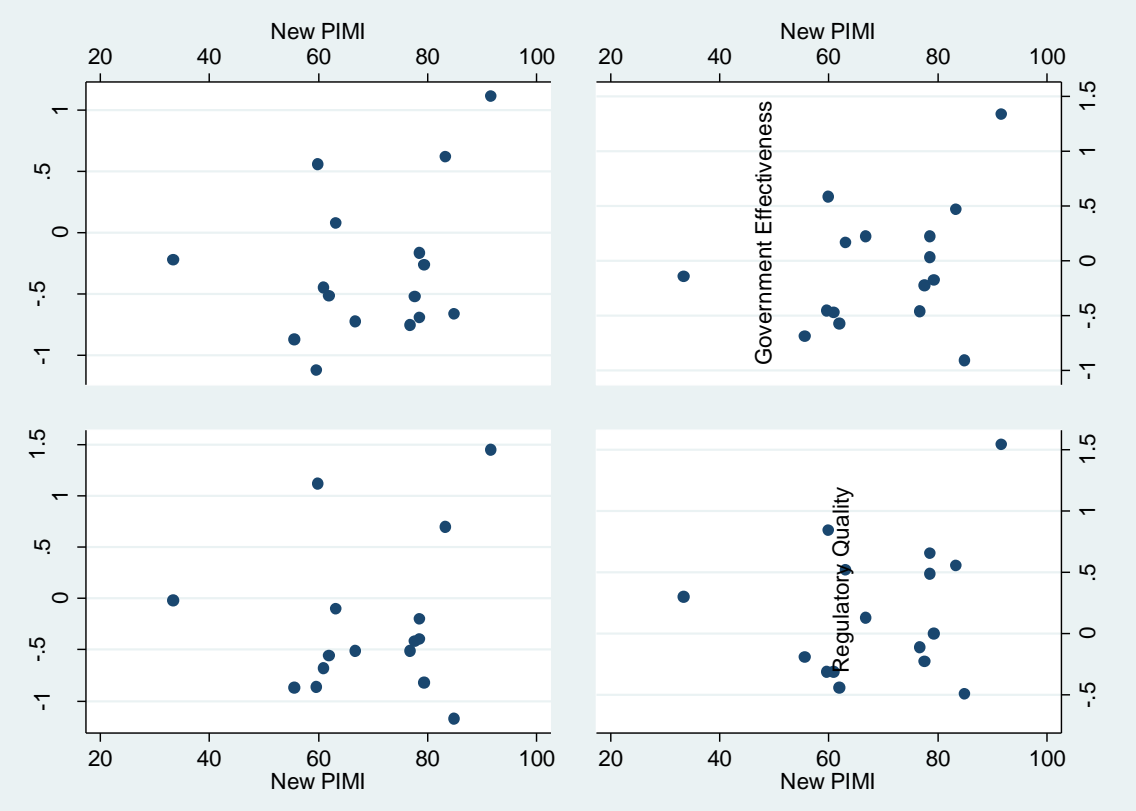

Figure 3. New PIMI against other institutional indices

Source: Authors' calculations

Table 5. Spearman correlations among PIMI and New PIMI with other indices

\begin{tabular}{|l|c|c|}
\hline Index & PIMI & New PIMI \\
\hline $\begin{array}{l}\text { Public Investment Efficiency (with no consideration } \\
\text { of depreciation) }\end{array}$ & -0.09 & 0.52 \\
\hline $\begin{array}{l}\text { Public Investment Efficiency (assuming an invariant } \\
\text { three percent annual depreciation rate) }\end{array}$ & -0.24 & 0.15 \\
\hline Government Effectiveness & 0.34 & 0.31 \\
\hline Control of Corruption & 0.18 & 0.16 \\
\hline Regulatory Quality & 0.39 & 0.26 \\
\hline Political Stability & 0.10 & 0.16 \\
\hline Rule of Law & 0.24 & 0.29 \\
\hline
\end{tabular}

Source: Authors' calculations based on World Governance Indicators (WGI), Dabla-Norris et. al. (2012), and IMF (2019). Institutional indices from WGI correspond to the year 1996.

\section{Concluding remarks}

The efficiency of public investment and its management are hard-to-measure variables. Dabla-Norris et. al. (op. cit) proxied this efficiency by constructing indices that aggregate indicators across four key stages of the investment process. These indices were then aggregated in the PIMI, which is the most widely used indicator of quality in public investment management. However, the PIMI was constructed with non-open access information and shows a correlation that deviates from the expected when plotted against a direct and objective indicator of public investment efficiency (PIE). 
In this paper, we built a New PIMI that takes into account the most recognized features that literature suggests as desirable traits for an adequate public investment system, and calculate it for the cases of sixteen Latin American countries. This new index relies on public access information, which makes it easily replicable and applicable to other countries as well. A key difference between the New and the original PIMI is that the former has a much better tracking performance of the PIE.

Nonetheless, the New PIMI's correlation with PIE has margin to be strengthened, which indicates that our new index can still be improved. Moreover, the PIE itself has limitations that need to be addressed, among them that its construction relies on very strict assumptions regarding the depreciation rate of public fixed capital stock between countries. Little is known about this variable at the aggregated level. Our results, on Latin America, lead to the main conclusion that the management of public investment in Chile, Paraguay, and Costa Rica compound the top three highest ranked in the region for almost all the alternative weighting scheme here considered. On the other hand, Brazil is by far the worst performer, followed by El Salvador, Guatemala, and Uruguay.

\section{References}

[1] Afonso, A., St. Aubyn, M. (2018). Economic growth, public, and private investment returns in 17 OECD economies. Portuguese Economic Journal, 18, 47-65. doi: 10.1007/s10258-018-0143-7

[2] Albino-War, M., Cerovic, S., Grigoli, F., Flores, J. C., Kapsoli, J., Qu, H., Said, Y., Shukurov, B., Sommer, M., Yoon, S. (2014). Making the most of public investment, Washington DC, USA: International Monetary Fund https://doi.org/10.5089/9781498311397.006

[3] Ahmad, E., Viscarra, H. (2016). Public Investment for Sustainable Development in Chile. Building on the National Investment System. IDB Discussion Paper No. 469. Washington D.C, USA: Inter American Development Bank._https://doi.org/10.18235/0000431

[4] Armendáriz, E., Contreras, E., Orozco, S., Parra, G. (2016). La eficiencia del gasto de inversión pública en América Latina. XXI Congreso Internacional del CLAD sobre la Reforma del Estado y de la Administración Pública, Santiago de Chile, November. https://doi.org/10.18042/cepc/rap.199.02

[5] Asamblea Legislativa de la República de Costa Rica (1974, May 18). Ley 5525. Ley de Planificación Nacional https://www.mideplan.go.cr/marco-legal-inversion-publica

[6] Asamblea Legislativa de la República de Panamá (2001, December 11). Decreto Ejecutivo $\mathrm{N}^{\circ} 148$. Gaceta Oficial $\mathrm{N}^{\circ}$ 24,458. https://docs.panama.justia.com/federales/decretos-ejecutivos/148-de2001-dec-26-2001.pdf

[7] Cámara de Diputados de los Estados Unidos Mexicanos (2006, March 6). Ley Federal de Presupuesto y Responsabilidad Hacendaria. Diario Oficial de la Federación http://www.diputados.gob.mx/LeyesBiblio/pdf/LFPRH_191119.pdf

[8] Congreso de la Nación Argentina (1994, July 28). Ley de Inversión Pública $\mathrm{N}^{\circ} 24.354$. https://www.argentina.gob.ar/dnip/normativa

[9] Congreso de la Nación Paraguaya (2020, January 6). Ley 6490. Ley de Inversión Pública. http://snip.hacienda.gov.py/Snip_Web/portal/marco_normativo.html

[10] Congreso de la República de Colombia (2013, May 21). Resolución 1450. https://www2.dnp.gov.co/programas/inversiones-y-finanzas-publicas/Paginas/marco-legal.aspx

[11] Congreso de la República de Guatemala (1997, December 12). Decreto N 114-97. Diario de Centro América 
https://www.minfin.gob.gt/images/downloads/dcp_marcolegal/bases_legales/DECRET0\%2011497.pdf

[12] Congreso Nacional de la República Dominicana (2006, December 27). Ley 498-06. Ley de Planificación e Inversión Pública https://www.transparencia.portuaria.gob.do/ley-498-06-ley-de-planificacion-einversion-publica-no-498-6

[13] Contreras, E., Cartes F., Pacheco, J. F. (2010). Los SNIP de América Latina y el Caribe: Historia, evolución y lecciones aprendidas. Documentos de Trabajo, Serie Gestión No. 124, Instituto Latinoamericano y del Caribe de Planificación Económica y Social (ILPES), CEPAL. https://doi.org/10.18235/0001952

[14] Dabla-Norris, E., Brumby, J., Kyobe, A., Mills, Z., Papageorgiou, C. (2012). Investing in Public Investment: An Index of Public Investment Efficiency. Journal of Economic Growth, 17, 235-266. doi.org/10.1007/s10887-012-9078-5

[15] Das, R., Das, C., Ray, K. (2018). Examining Forward and Backward Linkages Between Public and Private Investments. Review of Market Integration, 10, 45-75. https://doi.org/10.1177/0974929218761080

[16] Fontaine, E. (1997). Project Evaluation Training and Public Investment in Chile. American Economic Review, 87, Papers and Proceedings of the Hundred and Fourth Annual Meeting of the American Economic Association, May, 63-67.

[17] Gómez-Lobo, A. (2012). Institutional Safeguards for Cost-Benefit Analysis: Lessons from the Chilean National Investment System. Journal on Benefit Cost Analysis, 3, 1-30. https://doi.org/10.1515/21522812.1102

[18] Grigoli, F., Mills, Z. (2014). Institutions and public investment: an empirical analysis. Economics of Governance, 15(2), 131-153. doi:10.1007/s10101-013-0137-y

[19] Gupta, S., Kangur, A., Papageorgieu, C., Wane, A. (2014). Efficiency-Adjusted Public Capital and Growth. World Development, 57, 164-178. doi.org/10.1016/j.worlddev.2013.11.012

[20] Harberger, A. (1971). Three Basic Postulates for Applied Welfare Economics: An Interpretive Essay. Journal of Economic Literature, 9, 785-797

[21] International Monetary Fund (2015). Making public investment more efficient. Staff Report. Washington D.C.

[22] International Monetary Fund (2019). Estimating the stock of public capital in 170 countries. August 2019 update.

[23] Jay-Hyung, K., Fallov, J. A, \& Groom, S. (2020). Public Investment Management Reference Guide. International Development in Practice. World Bank

[24] McKinsey Global Institute (2013). Infrastructure productivity: how to save \$1 trillion a year (full report). New York, USA.

[25] Ministerio de Desarrollo Social y Ministerio de Hacienda de la República de Chile (2020, May 14). Ord. $\mathrm{N}^{\circ} \quad 1611 . \quad \mathrm{http} / /$ sni.ministeriodesarrollosocial.gob.cl/evaluacion-iniciativas-deinversion/evaluacion-ex-ante/normas-instrucciones-y-procedimientos-inversion-publica-nip/

[26] Ministerio de Finanzas del Ecuador (2010, October 19). Código Orgánico de Planificación y Finanzas Públicas content/uploads/downloads/2012/09/CODIGO_PLANIFICACION_FINAZAS.pdf

[27] Ministerio de Hacienda de la República de Bolivia. (1990, July 20). Ley 1178. Sistema Nacional de Inversión Pública. Normas básicas https://medios.economiayfinanzas.gob.bo/MH/documentos/normas_leyes/normas/NB-SNIP.pdf

[28] Ortegón, E., Pacheco, J. F. (2005). Los sistemas nacionales de inversión púbica en Argentina, Brasil, México, Venezuela y España como caso de referencia (cuadros comparativos). Santiago: CEPAL.

[29] Perroti, D., Vera, M. (2015). Avances y retos de los Sistemas Nacionales de Inversión Pública en América Latina. Resultados de la encuesta 2014. Serie Gestión Pública: Santiago CEPAL. https://doi.org/10.18235/0001952 
[30] Presidência da República (2000, May 4). Lei Complementar $N^{\circ}$ 101. Lei de Responsabilidade Fiscal. http://www.planalto.gov.br/ccivil_03/leis/lcp/lcp101.htm

[31] Presidencia de la República de Nicaragua (2001, June 26). Decreto $\mathrm{N}^{\circ}$ 61-2001. http://www.snip.gob.ni/Normativa/MarcoLegal

[32] Presidencia de la República del Uruguay (2012, November 22). Ley 18.996. Ley de Rendición de Cuentas y Balance de Ejecución Presupuestal. Diario Oficial de la Federación $\mathrm{N}^{\circ} 28601$ https://www.bps.gub.uy/bps/file/13503/1/snip-ley18.996.pdf

[33] Presidencia del Perú (2000, June 28). Ley 27293. Ley del Sistema Nacional de Inversión Pública. https://www.mef.gob.pe/es/normatividad-inv-publica/archivos-historicos/temas-historico/delsistema-nacional-de-inversion-publica-snip

[34] Pritchett, L. (2000). The tyranny of concepts: CUDIE (cumulated, depreciated, investment effort) is not capital. Journal of Economic Growth, 5, 361-384. doi.org/10.1023/A:1026551519329

[35] Rajaram, A., Le, T., Biletska, N., Brumby, L. (2010). A Diagnostic Framework for Assessing Public Investment Management. World Bank Policy Research Working Paper No. 5397: Washington: World Bank. https://doi.org/10.1596/1813-9450-5397

[36] Rajaram, A., Le T., Kaiser, K., Kim, J., \& Frank, J., Eds. (2014). The Power of Public Investment Management: Transforming Resources into Assets for Growth. Directions in Development. Washington DC, USA: World Bank. doi:10.1596/978-1-4648-0316-1

[37] Rojas, A. (2019). Inversión pública en Chile y México: Dinámica y marco institucional desde una perspectiva comparativa. Tesis de Maestría, UNAM

[38] Romp, W., De Haan, J. (2007). Public Capital and Economic Growth: A Critical Survey. Perspektiven der Wirtschaftspolitik, 8, 6-52. https://doi.org/10.1111/j.1468-2516.2007.00242.x

[39] Sánchez, R., Lardé, J., Chauvet, P., Azhar, J. (2017). Inversiones en infraestructura en América Latina. Tendencias, brechas y oportunidades. Santiago de Chile: CEPAL

[40] Schündeln, M. (2013). Appreciating depreciation: physical capital depreciation in a developing country. Empirical Economics, 44, 1277-1290. doi.org/10.1007/s00181-012-0592-2

[41] Serebrisky, T., Suárez-Aleman, A., Pastor, C., Wholhueter, A. (2017). Increasing the efficiency of public investment delivery. Evidence-based potential efficiency gains in public infrastructure investment in Latin America and the Caribbean. Technical Report. Washington DC: IDB. https://doi.org/10.18235/0000846

[42] Suárez-Alemán, A., Serebrisky, T., Perelman, S. (2019). Benchmarking economic infrastructure efficiency: How does the Latin American and Caribbean region compare? Utilities Policy, 58, 1-15. doi.org/10.1016/j.jup.2019.03.003

[43] Sturm, J.E., Kuper, G. H., De Haan, J. (1998). Modelling Government Investment and Economic Growth on a Macro Level: A Review. In S. Brakman, H. van Ees and S.K. Kuipers (eds.), Market Behaviour and Macroeconomic Modelling (pp.359-406) London, UK: Macmillan Press. https://doi.org/10.1007/9781-349-26732-3_14

[44] Vizzio, M. A. (2000). Los sistemas de inversión pública en América Latina y el Caribe. Santiago de Chile: CEPAL. 